\title{
ŚWIADOMOŚĆ ZMITOLOGIZOWANA - O KONTRKULTUROWYM MANIFEŚCIE, KTÓREGO NIE BYŁO
}

Tomasz Maślanka

Uniwersytet Warszawski

Artykuł ten jest próbą odczytania napisanej w 1967 roku przez Leszka Kołakowskiego rozprawy Obecność mitu jako tytułowego kontrkulturowego manifestu, którym oczywiście w intencjach jego autora nie był. Biorąc pod uwage specyficzny polski kontekst historyczny powstania tej pracy, bezpośrednio poprzedzający wydarzenia z marca 1968 roku, do którego w dalszej kolejności się odniosę, można by nawet posunąć się do stwierdzenia, że impulsem do napisania Obecności mitu była kontestacja ideologii PRL-u. Chciałbym nieco uwagi poświęcić tutaj również zadaniu fragmentarycznej choćby rekonstrukcji doświadczeń ludzi żyjących, mówiąc nieco górnolotnie, w czasach kryzysu idei, rozchwiania tożsamości i zadających sobie fundamentalne pytania o to, skąd jesteśmy i dokąd idziemy. Doświadczenia takie zwykło się nazywać pokoleniowymi, a w ich rekonstrukcji pomóc może, jak sądzę, odwołanie się do tej konkretnie pracy Kołakowskiego, jak również zakreślenie szerszego pola, w obrębie którego pytania takie mogły zostać postawione. Pytania, stanowiące - jak będę w dalszej części argumentował - owoc działalności świadomości mitotwórczej w rozumieniu Kołakowskiego. Ponadto odtworzenie samej struktury świadomości mitycznej, któremu poświecę w tekście więcej miejsca, jeszcze dobitniej ilustruje przekonanie amerykańskiego socjologa Jeffreya Alexandra o mitologiczno-rytualnych właściwościach współczesnych społeczeństw (Alexander 1987).

\section{/// Marksizm jako ideologia i postępowa narracja}

Jedna z najważniejszych, jeśli nie najważniejszą konstrukcją intelektualną ustanawiająca sens dla pokolenia ' 68 był niewattpliwie marksizm. 
Wyzwalanie się z okowów marksistowskiej iluzji proponuję za Lidią Burską ująć hasłowo jako „demontaż utopii”, rozumiany jako rodzaj autokonfrontacji z rozpoznaną u samych siebie fałszywą świadomością (Burska 2012: 12). Losy entuzjastycznej recepcji, a później całkowitej refutacji filozofii Marksa przez kontrkulturowe pokolenie lat 60 . są w tym wypadku kluczowe nie tylko dla uchwycenia przeobrażeń samego marksizmu, lecz także dla zrozumienia dynamiki pokoleniowej przemiany oraz procesów zachodzących wewnątrz kontrkulturowej ideologii. Należy na wstępie podkreślić, że fascynacja marksizmem wynikała u wielu intelektualistów właśnie z owej metafizycznej potrzeby tkwiącej w micie. „Marksizm objawił mi się jako siła porządkująca historię, życie społeczne i biografię ludzką. Potrzeba uporządkowania zrodziła się we mnie w wieku kryzysowym. [...] Marksizm poddawał mi się sam z prostymi formułami dotyczącymi wolności, historii, pracy, społeczności” - wyznawał Andrzej Kijowski, krakowski intelektualista i jeden z głównych przedstawicieli krakowskiej szkoły krytyki literackiej (Kijowski 1985). W przypadku fascynacji Leszka Kołakowskiego filozofią Marksa można mówić także o swoistych antywzorach polskiej tradycji kulturowej, którą Gombrowicz wywodził od Sienkiewicza, z jej klerykalizmem, antysemityzmem i wybujałą bigoteria (Gombrowicz 1997). To one pchnęły go w objęcia marksizmu, postrzeganego w owym czasie jako kontynuacja tradycji oświeceniowej, pozostającej w opozycji do sarmacko-szowinistycznej tradycji narodowej. Zafascynowanie młodego Kołakowskiego marksizmem (czy komunizmem) uznać można za element dosyć powszechnej wiary zachodnioeuropejskiej lewicy $\mathrm{w}$ to, że historyczna rola inteligencji polega na partycypacji w budowaniu racjonalnej, zgodnej z rytmem dziejów cywilizacji. Fakt ten ściagnął zresztą na wielu intelektualistów falę krytyki i zarzutów. W szczególności zaangażowanie intelektualistów w komunizm mogło sprawiać wrażenie, że ideologia ta posiadała jakieś drugie, ezoteryczne, dostępne jedynie dla wtajemniczonych dno, głębszą warstwę mądrości (Legutko 1999: 26). Podobnie Czesław Miłosz, analizując w Zniewolonym umyśle komunizm w kategoriach historiozoficznych, dokonał swoistej apoteozy tej ideologii, sugerując ponadto, że aprobata dla komunizmu miała intelektualny charakter (1999: 25-103). Dla Zbigniewa Herberta czy Gustawa Herlinga-Gruzińskiego sprawa akcesu była znacznie prostsza, powodem był strach przed terrorem komunistycznym.

Kluczem do zrozumienia filozofii Marksa jest zdaniem Kołakowskiego antropologia - stara się on rozwiązać przede wszystkim pewien dylemat filozoficzny i odpowiedzieć na pytanie, jak pogodzić racjonalna świadomość z nieracjonalnym światem, jak pojednać człowieka ze światem 
oraz z samym sobą (Kołakowski 1988). W tym znaczeniu Marks pozostaje dziedzicem tradycji niemieckiej filozofii idealistycznej, przede wszystkim Kanta i Hegla. Począwszy od rozległego opracowania poświęconego wewnętrznemu zróżnicowaniu, genezie oraz odłamom marksizmu, dostrzec można ślady tego, co z czasem ewoluuje w kierunku koncepcji świadomości mitycznej. Dlatego chciałbym w tym miejscu poświęcić nieco uwagi istotnej dla prezentacji ewolucji myśli Kołakowskiego książce Główne nurty marksizmu. Niech potwierdzeniem tej intuicji będzie znamienne ostatnie zdanie $\mathrm{z}$ monumentalnej trylogii Kołakowskiego, podsumowujące niejako zagmatwane losy myśli marksistowskiej i świadczące o rozczarowaniu samego autora jakimikolwiek wariantami ideologicznego odchylenia: „Samoubóstwienie człowieka, któremu marksizm dał filozoficzny wyraz, kończy się tak samo, jak wszystkie, indywidualne i zbiorowe próby samoubóstwienia - ukazuje się jako farsowa strona ludzkiej niedoli” (1988: 1212). Warto tutaj zaznaczyć, że ostanie tomy trylogii, w których pojawia się wyraźnie polemiczny i krytyczny ton, powstawały w połowie lat 70 ., czyli już po doświadczeniach roku 1968. Od samego jednak początku Kołakowski traktował marksizm jako filozofię, a nie program polityczny czy rozbudowany opis kapitalistycznej ekonomii. Główne nurty marksizmu pozostają w związku z tym po dziś dzień dziełem oryginalnym, stanowiącym świadectwo powikłanych losów gorliwego marksisty, później rewizjonisty i wreszcie krytyka Marksa, nie zaś czysto podręcznikową rekonstrukcję poglądów rozmaitych filozofów, teoretyków kultury czy szkół intelektualnych nawiązujących do Marksa, choć taki podręcznikowy profil był początkowo zamysłem autora. O oryginalności interpretacji filozofii Marksa dokonanej przez Kołakowskiego zadecydowało kilka elementów. Przede wszystkim Kołakowski wyróżnia w marksizmie trzy motywy: pierwszy, motyw romantyczny, rozumiany jest jako protest przeciwko przemianom społeczeństwa industrialnego, w wyniku których dochodzi do destrukcji tradycyjnych więzi społecznych. To motyw pojawiający się także w tęsknocie Ferdynanda Tönniesa za Gemeinschaft, która zostaje zastępowana przez Gesellschaft z dominującą rolą więzi formalnych (por. Tönnies 2008). Utopia Marksa polega na wierze, że w przyszłym świecie zniesiona zostanie wszelka mediacja między jednostką a społeczeństwem, słowem: znikną struktury pośredniczące, takie jak naród, państwo, prawo, i dokona się skok do królestwa wolności - bezklasowego społeczeństwa (Kołakowski 1988, Walicki 1996). Drugi motyw, prometejsko-faustyczny, związany jest z historyczna rola proletariatu, tego nowego kolektywnego Prometeusza ludzkości, podmiotu mającej nadejść rewolucji. Marksizm łudzi się nadzieją świeckiego zbawienia w czasie historycznym, będącego efektem działania 
człowieka, a nie Boga. Motyw ten zawiera zatem wątek soteriologiczny, a ściślej - opiera się na świeckiej autosoteriologii. Trzeci wreszcie motyw to racjonalistyczny, deterministyczny i oświeceniowy, który legł niewątpliwie u podstaw fascynacji Kołakowskiego myślą Marksa. Wyraża się on przede wszystkim w koncepcji materializmu dialektycznego i materializmu historycznego, mających wyjaśniać logikę procesu historycznego w kategoriach praw. Marksizm jest pod tym względem, na co zwrócił uwagę György Lukács, mitologiczny, to znaczy podlega epistemologicznym regułom mitu (Lukács 2013). Akceptując mit, akceptujemy jednocześnie jego treść oraz wartość, dlatego też marksizm nie jest po prostu jedną z wielu teorii opisujących rzeczywistość społeczną, ale równocześnie praktycznym aktem zaangażowania, z czego wynika jego odporność na zewnętrzną i racjonalną krytykę. Mówiąc najprościej, nie można zrozumieć właściwie marksizmu, nie będąc marksistą. Zatem rozumienie go jako teorii równoznaczne jest $\mathrm{z}$ aktem praktycznego i politycznego zaangażowania. Marksizm jest ponadto utopijny i silnie ideologiczny, a odwołując się do kryteriów naukowej prawomocności, chce uchodzić za wyraz „naukowego światopoglądu”. Kołakowski kreśli na kartach Głównych nurtów marksizmu obraz tej ideologii jako swoistej quasi-religii, podobnej do gnozy.

Światopogląd Kołakowskiego z tamtego okresu można by określić jako racjonalistyczny, ale w znaczeniu krytycznej refleksji, nie zaś jako pozytywistyczny racjonalizm zakorzeniony w tradycji kartezjańskiej. Jest to raczej racjonalizm odrzucający jako irracjonalne wszelkie światopoglądy obwieszczające absolutną wartość swoich twierdzeń. Racjonalizm Kołakowskiego jest radykalny, polega bowiem na odrzuceniu ostatecznych uzasadnień i absolutnej pewności. Jest to racjonalizm będący nieustanną herezja wobec każdej ortodoksji. $\mathrm{Na}$ jeden z wielu elementów tego światopoglądu składa się także przekonanie, że niemożliwe jest budowanie kultury w oderwaniu od świata wartości, nie tylko dlatego, że uznajemy jakieś wartości, a innym zaprzeczamy, lecz przede wszystkim dlatego, że są one konsekwencją ludzkiej aktywności, wywodzą się zatem z pnia praktycznego. Myśl ta zostanie rozwinięta właśnie w Obecności mitu. Wskazując na obecność trzech motywów w marksizmie, Kołakowski uzasadnia jednocześnie jego atrakcyjność, co pośrednio stanowi odpowiedź na pytanie, dlaczego stał się on podstawowym punktem odniesienia dla całego kontrkulturowego pokolenia.

Rewolta studencka '68, zwłaszcza w Europie Zachodniej, podszyta była zhumanizowanym wariantem marksizmu, który doskonale wyeksploatował w licznych pracach Erich Fromm (por. np. Fromm 2005: 205-295). Młodzi aktywiści pragnęli spełnienia marzeń o wolnym i sprawiedliwym, 
pozbawionym konfliktów oraz przemocy społeczeństwie, kreślili wizje jednostek twórczych i wyzwolonych ze zdehumanizowanej i wyalienowanej rzeczywistości zakładu pracy. Eric Hobsbawm tak podsumowuje bunt pokolenia '68: „Rewolta studencka z późnych lat sześćdziesiątych stanowiła ostatni wyczyn tradycyjnej światowej rewolucji. Była rewolucyjna zarówno w dawnym utopijnym sensie poszukiwania trwałego przewartościowania ideałów nowego i doskonałego społeczeństwa, jak i w sensie operacyjnym, zmierzała do tych celów przez uliczne działania i barykady, bomby i górskie zasadzki" (1999: 408). Sens operacyjny kontestacji, o którym tu mowa, pozostaje jednak wielce wattpliwy, zwłaszcza że wielu intelektualistów, w tym Kołakowski, zdawało sobie sprawę już na początku lat 70 . z fiaska kontrkultury jako ruchu dążącego do realizacji celów politycznych. W rozmowie ze Zbigniewem Mentzlem w mocno szyderczym tonie wypowiada się o młodych „,rewolucjonistach”: „Rewolucja, która przyniesie wyzwolenie. Z czego wyzwolenie? Ze wszystkiego! Jak wiadomo, studenci sa na świecie najbardziej uciskaną klasą społeczna. Cierpią wręcz straszliwy ucisk! Faszystowskie świnie z establishmentu zmuszają ich do nauki i, jakby tego jeszcze było mało, chca, aby zdawali egzaminy, zamiast bez pytania dawać wszystkim stopnie celujące. Wiele razy słyszałem, że nie ma najmniejszej, ale to najmniejszej różnicy między warunkami życia w kalifornijskim miasteczku uniwersyteckim i w obozie koncentracyjnym hitlerowskim czy stalinowskim. To dokładnie taka sama opresja. [...] Ci studenci nic nie wiedzieli o świecie, co nawet trudno im mieć za złe, bo ignorancja jest czymś naturalnym w młodości. Ale ich ideologia, jeśli w ogóle można tutaj mówić o ideologii, to był zlepek niekoherentnych haseł, z których nic określonego nie wynikało, poza dużą frustracją i jeszcze większą agresja. Takiej degradacji intelektualnej nie spotkałem nigdy przedtem w żadnym ruchu lewicowym" (Kołakowski 2008: 25-26). Allan Bloom, obserwujący wydarzenia '68 z perspektywy amerykańskiej, był jeszcze radykalniejszy w swoich opiniach na ten temat (por. Bloom 2012). Historycznie zatem rzecz biorąc, wywodząca się z kontrkultury lewica nie osiagnęła znaczących sukcesów w krajach Europy, gdzie dominujący okazał się wariant „mieszczański”, który w Stanach Zjednoczonych od samego początku określany był terminem „klasa średnia”.

Marksizm, socjalizm i komunizm postrzegane były w latach 60 . jako dziejowa awangarda w Europie Zachodniej, dlatego też ideologia marksistowska mogła wydawać się nieprzekraczalnym horyzontem dziejów. Jednak w tym samym mniej więcej czasie w krajach Europy Środkowo-Wschodniej jawiła się ona jako pozbawiony dziejowego znaczenia przeżytek. Być może, jak sugeruje Zbigniew Herbert, była to sprawa smaku. 
Z całą pewnością estetyka egzystencjalizmu i humanizmu, jak i ogólna intelektualna atmosfera, którą oddychali przedstawiciele lewicy paryskiej, diametralnie odbiegała od realiów PRL-u, od owej, jak określił to Stefan Kisielewski, „dyktatury ciemniaków”, której bezpieczeństwa strzegły oddziały Milicji Obywatelskiej oraz ZOMO. Wrogość młodych studentów pokolenia '68 w Europie Zachodniej do zastanego systemu była, można rzec, wrogością totalna, niechęcią do życia w jego ramach. Nie chodziło przy tym o sam system polityczny, lecz również o system aksjonormatywny, a zatem o wartości i wzory szczęśliwego, godnego życia i relacji międzyludzkich. Można oczywiście zadawać sobie pytanie, dlaczego akurat w czasach bezprecedensowej gospodarczej prosperity takie stabilne wzorce życia zostały zakwestionowane, co zachwiało cała struktura społeczną. Leszek Kołakowski, podkreślając rozróżnienie na „ich maj” i „nasz marzec", sugerował niespójność o charakterze politycznym: zachodnioeuropejskie zafascynowanie mitem rewolucji i wschodnioeuropejskie rozczarowaniem tym samym mitem, duchowy kryzys młodych mieszkańców Paryża i polityczny wymiar walki o wolność w naszej części Europy. Obecność mitu pokazuje jednak, że nie powinniśmy pochopnie szafować podobnymi rozróżnieniami. Sugestia, że źródłem zachodnioeuropejskiej rewolty był kryzys duchowy, a naszej - polityczny, jest w moim odczuciu niewłaściwa. Obecność mitu można próbować odczytać jako manifest zarówno wschodnio-, jak i zachodnioeuropejskiej kontrkultury, co pozwala uniknąć upraszczających twierdzeń, że bunt zachodniej młodzieży był zabawa rozkapryszonych dzieci, którym znudziły się stare zabawki, a ten wschodnioeuropejski - dojrzałą politycznie batalią o wolność. Sądzę, że można interpretować rewoltę jako odpowiedź na rozpad sensotwórczych metanarracji - heglizmu i przede wszystkim marksizmu, co wynika ze struktury mitotwórczej świadomości, a nie z doraźnych okoliczności politycznych. Dowodem na to może być i to, że właśnie marksizm uwiódł przedstawicieli kontrkultury, a nie opublikowana w 1971 roku, na fali renesansu normatywnej filozofii politycznej, liberalna normatywna teoria sprawiedliwości społecznej Johna Rawlsa (Rawls 2013). Stało się tak, ponieważ marksizm był nie tyle próba zniesienia, czyli wyjaśnienia społecznej niesprawiedliwości, ile poszukiwaniem sensu w obliczu niepewności. Można to również tłumaczyć obecnością wspomnianego motywu romantycznego w myśli Marksa, co wyjaśnia niechęć kontrkultury do liberalnej filozofii, a jego antyindustrialny charakter, odwołujący się do idei społeczeństwa wolnego od przymusu i zorganizowanego na zasadzie spontanicznych więzi jednostek ze wspólnotą, odnieść można wprost do kontrkulturowej idei komuny. W najogólniejszym sensie marksistowska wizja historii zakłada, 
że człowiek tworzy samego siebie poprzez niewyalienowaną pracę, która staje się źródłem jego autoafirmacji. Tym samym uznanie marksizmu za teoretyczna podbudowę jednej z dwudziestowiecznych ideologii pozbawia go najistotniejszego, jak sądzę, wymiaru, który sprowadza się do poszukiwania sensu poprzez praxis działań społecznych zmierzających do samourzeczywistnienia człowieka. W takiej perspektywie koncepcję świadomości mitycznej proponuję, mutatis mutandis, potraktować jako kontynuację tej wczesnej fascynacji Kołakowskiego.

\section{/// Korzenie religijnego myślenia i filozofia mitu}

Rozprawa o micie, która traktuję w tym artykule jako rodzaj wirtualnego pokoleniowego manifestu, może być moim zdaniem należycie zrozumiana w kontekście procesu intelektualnego dojrzewania jej autora. Jeśli spojrzeć na całokształt filozoficznego dorobku Kołakowskiego, to okaże się, że centralny obszar jego zainteresowań stanowią kwestie religii, poczynając od pracy Świadomość religijna i wię́ kościelna, po Jeśli Boga nie ma oraz Bóg nie jest nam nic dtu̇̈ny i wiele innych prac poświęconych filozofii religii. W swojej intelektualnej młodości Kołakowski w sposób dosyć napastliwy demonstrował własny antyklerykalizm, aby w końcu przejść swoistą ewolucję od błazna do kapłana, by posłużyć się tytułem jego znanego eseju. W szeroko dyskutowanym niegdyś tekście Kapłan i błazen Kołakowski postawił tezę o religijnych korzeniach nowoczesnego myślenia, do złudzenia przypominającą tezy Jeffreya Alexandra o tym, że współczesne społeczeństwa nigdy nie zostały w istocie „odczarowane” (Kołakowski 1989: 161-180, Alexander, Sherwood, Smith 1993). W okresie poprzedzającym publikację tego tekstu uważał jednak, że religia jest wyrazem stanu uśpienia świadomości oraz zatrucia jej przez wytwory chorego bytu społecznego. Religia ofiarowuje człowiekowi zatrute owoce zakłamanej nieśmiertelności, odbierając mu smak doczesnego życia. W tym okresie twórczości oraz rozwoju intelektualnego Kołakowskiego mieści się także, jak się wydaje, praca o Spinozie (Kołakowski 2012), interpretująca Spinozę jako prekursora Oświecenia, którego myśl cechuje racjonalizm i mechanistyczne tłumaczenie świata oraz walka o wyzwolenie człowieka od nacisku świadomości religijnej. Cel antropologiczny monizmu Spinozy jawi się jako emancypacja człowieka od transcendentnego Boga - nadprzyrodzonego prawodawcy i rozkazodawcy, źródła wszelkich upokorzeń rodzaju ludzkiego. Wyzwolenie człowieka jest u Spinozy możliwe jako negacja wszelkiej moralności posiadającej nadprzyrodzone uprawomocnienie, twierdzi Kołakowski. Etyka Spinozy pozbawiona jest 
zatem pozaziemskich sankcji oraz drogowskazów moralnych wybiegających poza świat doczesny (por. Kołakowski 2012).

Wyraźny przełom w myśleniu o religii zaczął się już pod koniec lat 60., kiedy to Kołakowski napisał wstęp do słynnego Traktatu o bistorii religii Eliadego (Eliade 2009) pod tytułem Miracea Eliade. Religia jako paraliz. çasu. Kołakowski rezygnuje z redukcjonistycznej i alienacyjnej koncepcji religii na rzecz tezy, że religia i przekonania religijne nie wyrażaja stanu fundamentalnej bezradności człowieka wobec przyrody. Obecność mitu stanowi, jak mi się wydaje, moment przełomowy w ewolucji intelektualnej Kołakowskiego. Przede wszystkim mit religijny rodzi się z potrzeby sensownego przeżycia świata jako całości. W latach 70. można obserwować całkowite porzucenie przez Kołakowskiego alienacyjnej koncepcji religii, będzie teraz akcentował konieczność istnienia sacrum dla zachowania równowagi w kulturze (Kołakowski 2006a). Religia, powiada Kołakowski, to sposób, w jaki człowiek akceptuje swoje życie jako nieuchronną porażkę (tamże: 244). Także obecność tradycji chrześcijańskiej w kulturze ma swoje uzasadnienie, ponieważ dysponuje ono językiem umożliwiającym opis sytuacji człowieka postawionego wobec zła, człowieka, którego rola polega na radykalnym odsłanianiu i niszczeniu zła w sobie. Stajemy się bowiem lepsi, kiedy uświadamiamy sobie, że rozumiemy własne zło. Obecność diabła (któremu Kołakowski poświęcił sporo uwagi) w chrześcijaństwie świadczy o tym, że poważnie podchodzi ono do problemu doświadczania zła przez człowieka (Kołakowski 2006b). W tym okresie Kołakowski staje się zwolennikiem czegoś, co można by określić jako „filozofię mitu” uznaje on religię za niezbędna dla człowieka, niemogącego pogodzić się z życiem jako nieuchronną klęską, ale jednocześnie decydującego się żyć (tzn. nie odbierać sobie życia). Filozofia mitu ma charakter postscjentystyczny i jest próbą przemyślenia kondycji człowieka poszukującego sensu w sytuacji załamania się mechanicystycznego światopoglądu naukowego. Filozofia ta nie jest jednak światopoglądem filozofa, lecz ma charakter wybitnie analityczny. Kulminacyjnym jej osiagnięciem jest właśnie rozprawa Obecność mitu, w której Kołakowski odwołuje się do mitu w znaczeniu, jakie nadał mu Mircea Eliade: odkrywania przez człowieka absolutnie początkowej sytuacji, która ma moc nadawania sensu działaniom życia codziennego poprzez odnoszenie ich do instancji (rzeczywistości) o charakterze nierelatywnym (Eliade 2008). Podstawową funkcją mitu jest zdaniem Kołakowskiego porządkowanie w sensowna całość rozproszonych danych doświadczenia poprzez odnoszenie ich do „pozaempirycznej realności bezwarunkowej”, a zatem instancji o nierelatywnym charakterze (Kołakowski 1972: 14). Dla Kołakowskiego obecność mitu w każdej 
kulturze jest niewątpliwa, świadomość i światopogląd mityczny stanowia nieodłączny element każdej kultury. Mit jest, mówiąc jeszcze inaczej, sposobem organizacji ludzkiej świadomości, której struktura jest konstytuowana przez trzy fundamentalne potrzeby egzystencjalne: potrzebę wiary w celowy ład świata, potrzebę wiary w trwałość ludzkich wartości, niezależnych od partykularnych i historycznie zmiennych okoliczności, oraz potrzebę widoku świata jako ciagłego. Te trzy elementarne potrzeby, jak stwierdza Kołakowski w Obecności mitu, dają się sprowadzić do fundamentalnej niezgody człowieka na świat przypadkowy, akcydentalny (tamże: 14-18). Jan Andrzej Kłoczowski zwrócił uwagę, że analizowane przez Kołakowskiego potrzeby metafizyczne sa zbieżne z trzema ideami rozumu z Kantowskich Krytyk. Rozumiejące ogarnięcie realności empirycznej jest odpowiednikiem idei Boga, ponieważ jego istnienie umożliwia człowiekowi postrzeganie świata jako struktury znaczące; wiara w trwałość ludzkich wartości ma odpowiednik w idei nieśmiertelnej duszy; potrzeba oglądu świata jako ciąłłego zaś - w idei jedności świata (Kłoczowski 1994: 171). Akt afirmacji przygodnego świata niechybnie przerodzić się musi w całkowity paraliż ludzkiej aktywności w świecie społecznym. Oznacza także, a może przede wszystkim, destrukcję symboliczno-aksjologicznej tkanki kultury. Pozbawiona mitycznego odniesienia kultura pozostawałaby niezdolna do udzielania odpowiedzi na egzystencjalne pytania ludzi, czyli pytania wykraczające poza to, co bezpośrednio dane. Kategoria „pozaempirycznej realności bezwarunkowej”, która posługuje się Kołakowski w Obecności mitu, wskazuje w istocie w sposób jednoznaczny na konieczność istnienia takiej realności, której istnienie byłoby niezależne od świadomości podmiotu, a która stanowiłaby jednocześnie warunek możliwości istnienia takiej świadomości. Mit jest ponadto warunkiem percepcji siebie jako pewnej sensownej całości wyodrębniającej się z danego tout court otoczenia. Jest zatem warunkiem możliwości powstania narracji tożsamościowej. Szczególnym przypadkiem mitu w kulturze europejskiej jest mit rozumu, wiara w rozum, która jak powiada Kołakowski, ,jest potrzebna, aby człowieczeństwo mogło ukonstytuować się jako obecność Rozumu w nierozumnym świecie" - wiara wynikająca z podstawowej ludzkiej niezgody na intelektualna przypadkowość (Kołakowski 1972: 68). Ważność mitycznego pnia kultury Kołakowski rozszerza zatem także na świat wartości epistemologicznych i w ten sposób prawda staje się dla niego mitem, podobnie jak produkujący ją rozum. Rozum i prawda stają się więc przedmiotem zawierzenia, a nie dowodzenia.

Aby znaleźć trwałe oparcie w życiowym procesie, który dla nas ludzi jest procesem historycznym, także niezbędne jest istnienie świadomości 
mitycznej. Sprawia ona, że dzieje stają się pewną sensowną całością, a ich sens nie wyczerpuje się w szeregu przypadkowych transformacji empirycznych wydarzeń. Inaczej mówiąc, mit sprawia, że historia nie jest ślepa, tragiczna i bezrozumna, ale przeciwnie, jest sensowna i zmierza ku czemuś, co oczywiście nie oznacza, że żądzą nią jakieś prawa w sensie Heglowskim czy Marksowskim. Mit historii, występujący pod postacią rozmaitych historiozofii (np. marksizm, chrześcijaństwo, teorie postępu), odgrywa rolę analogiczną do mitu rozumu, wyrastając z fundamentalnej niezgody na wizję świata jako chaosu nic nieznaczących oraz niepowiązanych ze sobą wydarzeń. Mit taki daje człowiekowi poczucie choćby prowizorycznego zakorzenienia i zaufania, nie zezwalając na egzystencjalną rozpacz w obliczu bezmiaru cierpień, jakimi przepełnione sa dzieje świata. Świadomość mityczna stanowi w tym wypadku źródło sensu zarówno historii, jak i teraźniejszości, pozostając remedium na „fenomen obojętności świata”. Fenomen obojętności świata jest tym, od czego uciekamy i ucieczka ta stanowi sens naszych dążeń na tym świecie, twierdzi Kołakowski (tamże: 111). Fenomen obojętności świata szczególnie wyraziście manifestuje się w bólu fizycznym, kiedy doświadczamy swoistego rozdwojenia na obce (bolące) ciało i świadomość, a także w antycypacji śmierci własnej, czyli w wyobrażeniu świata bez naszej w nim obecności. Podejmujemy rzecz jasna nieustanne próby przezwyciężania owego fenomenu: w aktach miłości (także cielesnej), w próbach zawłaszczania rzeczywistości fizycznej poprzez fakt posiadania rzeczy (także ich nabywania), poprzez techniczne opanowywanie rzeczywistości - wszystkie te próby pozostaja jednak daremne i bezskuteczne (tamże: 111-122), ponieważ obojętność nie stanowi właściwości świata jako takiego, lecz jest zjawiskiem zachodzącym dla świadomości intencjonalnie do tego świata odniesionej. Kołakowski, podobnie jak Husserl, zwraca uwagę na paradoks ludzkiej podmiotowości: człowiek z jednej strony jest podmiotem dla świata, z drugiej zaś przedmiotem w świecie. Posiada wyróżniająca go od pozostałych żyjących istot zdolność czynienia własnej świadomości przedmiotem refleksji, lecz to właśnie ta swoiście ludzka zdolność samouprzedmiotowienia sprawiła, że człowiek stał się dla siebie samego niezrozumiały jako podmiot. Recepta na uzdrowienie naszego samorozumienia to właśnie mit, dzięki niemu bowiem człowiek ma szansę na umiejscowienie siebie w porządku pozaempirycznym i tym samym odniesienie swojej egzystencji do jakiegoś transcendentnego ładu - tym samym nadanie jej sensu. Uniwersalność mitu przejawia się zatem jako uniwersalność mitotwórczej pracy naszej świadomości. Nietrudno spostrzec, że owe zasadnicze egzystencjalne potrzeby, które konstytuują strukturę świadomości mitycznej, oznaczają de 
facto opowiedzenie się za jakimś rodzajem zależności i posłuszeństwa oraz rezygnację z wolności i autonomii. Oczywiście istnienie potrzeby odnoszenia własnego bytu do realności bezwarunkowej świadczy tylko o istnieniu takiej intencji, nie stanowi natomiast dowodu na obecność tego, do czego owa intencja się odnosi. Intencjonalna obecność mitycznych konstruktów w naszej kulturze stanowi jedynie ujawnienie tej potrzeby wbudowanej w realność bytu ludzkiego (tamże: 14). Absurdalność świata nie tkwi immanentnie w samym świecie, jak utrzymuja egzystencjaliści, lecz ujawnia się, kiedy próbujemy uznawać świat za realność samowystarczająca. Absurd jest więc ujawnieniem dwóch odmiennych sposobów istnienia człowieka i świata rzeczy. Dopiero w mitycznej perspektywie można odsłonić świat wartości. W perspektywie tej prawda, podobnie jak rozum, okazują się mitem, posługiwanie się tymi kategoriami stanowi zaś swoiście ludzki sposób odnoszenia się do świata - człowieka jako istoty wartościującej. Dlatego też mit nie może być oceniany za pomocą kryteriów kognitywnych ani estetycznych, gdyż przyjęcie mitycznej perspektywy jest otwarciem się na świat wartości. Mit odsyła do obszaru niezagospodarowanego przez technologię. Filozofia mitu jako rekonstrukcja pracy mitycznej świadomości jest częścia filozofii kultury Kołakowskiego. Obecność mitu odczytywać można więc również jako wyraz rozczarowania technologią.

Mit jest ponadto pewną formą narracyjną (Ricoeur 1986), która umożliwia symbolom kulturowym transformację w określone modele życia społecznego. W tym sensie pokolenie '68 tworzyło własną kontrkulturowa narrację, przedstawiając siebie i w określony sposób o sobie opowiadając. Obecność mitu stanowi część tej opowieści, wpisując się w ideowy klimat tamtych lat. Pokolenie ' $68 \mathrm{w}$ Polsce kształtowało się, jak powszechnie wiadomo, w wirze wydarzeń marcowych, dla których cezurę stanowi incydent zdjęcia z afisza Mickiewiczowskich Dřiadów w inscenizacji Kazimierza Dejmka. Obok upolitycznionej frakcji tzw. „Komandosów” istniały stosunkowo słabo zbadane apolityczne odłamy polskiej kontrkultury (hipisi, osoby skupione wokół ruchu psychiatrii humanistycznej założonego przez Kazimierza Jankowskiego, artyści, inteligenci bez wyraźnych skłonności politycznych, młodzi buddyści etc.). Pokolenia '68 w Polsce nie można zatem ograniczać, jak to się często czyni, do niedojrzałych rewizjonistów z grupy „Komandosów” z jednej i literackiej Nowej Fali z drugiej strony. Niemniej historia tego pokolenia zaczyna się od pamiętnego wiecu na Uniwersytecie Warszawskim, który był jego mitem fundacyjnym, a w każdym razie początkiem narracji o przepojonych duchem braterstwa i solidarności młodych buntownikach. Młodzieńczy entuzjazm i emocje zdawały się wówczas górować nad świadomościa polityczną. 
Jak pisze Lidia Burska w książce poświęconej pokoleniu '68 W Polsce: „Marzec mógłby stać się także integralną częścią opowieści wywodzącej się wprost z dziewiętnastowiecznego, anachronicznego dramatu narodowego pod tytułem «Niepodległość bez cenzury». [...] Marzec byłby w tej opowieści fragmentem heroicznego mitu opozycji politycznej, rodzenia się narodowej solidarności, jednym z ważnych aktów założycielskich III Rzeczpospolitej. Spór o to, jak wykorzystać pamięć '68 roku w opowieści o niepodległości, dopiero się rozpoczyna” (2012: 66). Polski marzec jest też fragmentem globalnego fenomenu kontrkultury lat 60., stanowiącego prawdziwy wachlarz kulturowo-politycznych opcji, od lewicowego radykalizmu do ruchów funkcjonujących w "giętkich ramach działania”, takich jak choćby hipisi (Jawłowska 1975: 148-160). Spoglądając na ideowy klimat przełomu lat 60. i 70. należy również zwrócić uwagę, że były to próby budowania racjonalnego laickiego światopoglądu w opozycji do środowisk katolickich (mam tutaj na myśli zwłaszcza renesans egzystencjalizmu oraz personalizmu chrześcijańskiego, reprezentowany przez takich myślicieli jak Gabriel Marcel czy Emmanuel Mounier). Jacek Kuroń i Karol Modzelewski, autorzy słynnego Listu otwartego, wierzyli w tamtym czasie w możliwość uszlachetnienia marksizmu i niespecjalnie różnili się w tej wierze od zachodnioeuropejskiej lewicy. W tym samym mniej więcej czasie dawny ortodoksyjny marksista Kołakowski pisał Obecność mitu, którą odczytywać można, jak zostało już powiedziane, jako wyraz totalnego rozczarowania marksizmem, czy mówiąc bardziej wprost - przekonania, że nigdy nie miał on żadnego głębszego, drugiego dna. Dla Kołakowskiego marzec oznaczał $\mathrm{w}$ istocie koniec rewizjonizmu i pozbycie się iluzji ulepszania dyktatury proletariatu. Marksizm uchodził w latach 60., jak już wspominałem, za umysłową awangardę prawie na całym świecie, pośród środowisk lewicowych. Polska kontrkultura rozpoznała znacznie wcześniej to, co stało się doświadczeniem przełomowym pokolenia lewicy paryskiej, zwanego także „pokoleniem szoku Sołżenicyna”. W Polsce można było przekonać się naocznie o totalitarnym charakterze marksizmu na kilka lat przed tym, nim na Zachodzie ukazał się Archipelag Gułag Sołżenicyna. Jednocześnie w kulturze zachodnioeuropejskiej wyodrębnić można „frakcję kulturową” niezainteresowaną marksizmem jako filozofią dziejów, ale czerpiącą z tego dziedzictwa co najwyżej niektóre wątki humanistyczne i podkreślająca potrzebę samorealizacji, samodoskonalenia i pracy nad sobą. Podejmując w owym czasie pracę nad meandrami funkcjonowania świadomości mitycznej, Kołakowski bliższy był, jak mi się zdaje, tej właśnie frakcji. Skądinąd, patrząc z dzisiejszej perspektywy, trudno nam wyobrazić sobie, że przedstawiciele paryskiej lewicy, tacy jak Jean-Paul Sartre, Jean-Luc 
Godard, Michel Foucault czy Gilles Deleuze nie wiedzieli w latach 70. o istnieniu sowieckich gułagów. A jednak wiedza ta przyszła dopiero z lekturą opublikowanego na początku lat 70. na Zachodzie Archipelagu Gułag Aleksandra Sołżenicyna. Dopiero wówczas paryscy intelektualiści zorientowali się, że gułagi nie były koślawym urzeczywistnieniem komunistycznej utopii, lecz integralną częścią całego systemu. Musiał to być rodzaj wstrząsu moralnego, ponieważ apoteoza systemu komunistycznego oraz Związku Radzieckiego stanowiła element ich własnej buntowniczej ideologii. Po otrzaśnięciu się z tej koszmarnej wiedzy musiało nastąić ideologiczne przewartościowanie, które zaowocowało radykalnym sprzeciwem wobec systemu komunistycznego. Można nawet postawić tezę, że rozpad bloku wschodniego nie rozpoczął się ani od upadku muru berlińskiego, ani od transformacji ustrojowej w Polsce w 1989, ale właśnie wtedy, w połowie lat 70. w Paryżu, kiedy to czołowi przedstawiciele paryskiej lewicy stracili złudzenia. Po doświadczeniach pokolenia paryskiej lewicy można wyczuć klimat większej abstynencji intelektualnej i podejrzliwości wobec wielkich teorii i utopii społecznych.

Kontrkultura w Polsce była więc nie tyle reakcją na przełomowe polityczne wydarzenia, ile oporem wobec „martwego czasu, braku historii i braku nadziei" (Burska 2012: 123). Poza tym, o ile na Zachodzie studencka rewolta mogła uchodzić za wydarzenie o szerokim zasięgu oddziaływania, o tyle w Europie Środkowo-Wschodniej stanowiła raczej „wybryk garstki inteligentów", a zatem grup pochodzących z dużych miast, pisarzy, artystów. Warto o tym pamiętać, ponieważ świadomość zbiorowa młodych Francuzów czy Niemców była zupełnie inna niż mieszkańców Czechosłowacji czy Polski. Ta druga nie była zbiorową świadomością całego pokolenia, ale raczej świadomością wykluczonych.

Odwołanie się do koncepcji świadomości mitycznej stanowi próbę spojrzenia na kontrkulturę przez pryzmat analizy socjokulturowej, która nie ograniczałaby się do badania ideologii politycznej czy rozporządzeń państwowych kształtujących ład polityczny, lecz rekonstruowała zmiany, jakim podlegały zbiorowe wyobrażenia. Taka analiza pozostaje w harmonii z mocnym programem socjologii kulturowej Jeffreya Alexandra, akcentującym kulturowy charakter zmian społecznych. Autor ten pisze, że: „Nie jest możliwe, by społeczeństwo było zdominowane przez racjonalność technologiczna, ponieważ mentalne struktury ludzkości nie mogą zostać radykalnie uhistorycznione; w swych kluczowych wymiarach sa one niezmienne. Istoty ludzkie nadal doświadczaja potrzeby nadawania światu znaczenia metafizycznego i doświadczenia solidarności z obiektami znajdującymi się na zewnątrz osobowości. [...] Jednostki moga przejawiać 
naukowo racjonalne nastawienia $\mathrm{w}$ pewnych sytuacjach, ale nawet w tych przypadkach ich działania jako takie nie są naukowo racjonalne" (2010: 122). Cytat ten mógłby równie dobrze pochodzić z Obecności mitu Kołakowskiego, co skłania do przypuszczenia, że nasza świadomość jest strukturalnie mityczna. Ilustracją powyższego stwierdzenia może być uwikłanie kontrkultury w projekt nowoczesności oparty na idei postępu, także w marksistowskim wydaniu, co interpretować można jako wynik owej tęsknoty, by „ukonstytuowało się człowieczeństwo jako obecność rozumu w bezrozumnym świecie", jak ujął to Kołakowski w Obecności mitu. Ostatecznie chodzi zatem o sygnalizowany już wielki problem filozoficzny wyrażający się w dylemacie: jak pogodzić racjonalną świadomość z nieracjonalnym światem. Nerwem całej kontrkultury była, jak sądzę, potrzeba widoku świata jako sensowego i ciagłego, jedna $z$ trzech elementarnych potrzeb wyznaczających strukturę świadomości mitycznej. Pragnienie życia w świecie uporządkowanym i mającym sens skierowało uwagę najpierw na marksistowską historiozofię, a później na duchowy wymiar egzystencji, by posłużyć się niespecjalnie modnym współcześnie i nieco patetycznym określeniem. Warto też zaznaczyć, że wielu studenckich rewolucjonistów było początkowo zagorzałymi wrogami hipisowskiej kontrkultury (szczególnie w USA i we Francji). Ustawicznie podkreślali dzielącą ich przepaść, nie korzystali z używek, nie zwracali uwagi na modę, nie słuchali (przynajmniej do czasu) muzyki rockowej. Znamienne jest jednak to, jak szybko wygasał ów polityczny zapał. Już na poczattku lat 70. większość radykałów zajmowała się głównie buddyjską medytacją i ekologicznymi uprawami warzyw w przydomowych ogródkach. Bunt został oswojony i przyjął miękkie, rozbrojone i kulturowe oblicze.

$$
* * *
$$

Wyczerpanie się marksizmu jako ideologii oraz metanarracji nowoczesności było nieuniknione, co w zwięzły sposób podsumował Allan Bloom: „Mówiąc brutalnie, Marks się znudził - i to nie tylko amerykańskim nastolatkom. Na jakiejś głuchej prowincji zawziętych samouków być może porywa retoryka typu «Robotnicy wszystkich krajów...», a prezydenci jednopartyjnych państw Trzeciego Świata odwołują się do autorytetu Marksa, by uzasadnić swe antyzachodnie fobie. Jednakże w ośrodkach myśli, gdzie wszyscy są na bieżąco i gdzie wytwarza się ideologie, Marks jest już od dawna martwy" (2012: 284). Kontrkultura była jedną z takich alternatywnych ideologii, która oferowała to, czego próżno szukać nawet we wczesnych „humanistycznych” pismach Marksa - próbę odpowiedzi 
na pytanie, jak żyć w świecie, w którym bezlitośni kapitaliści nie zagarniaja już owoców pracy nieszczęsnych proletariuszy, a praca jest lub może być źródłem samoafirmacji. Innymi słowy, ani we wczesnych, ani w późnych pismach Marksa zrewoltowana młodzież nie mogła odnaleźć odpowiedzi na nurtujące ją quasi-religijne pytania o sens, wynikające ze struktury świadomości mitycznej. Obecność mitu nie jest oczywiście manifestem w normatywnym znaczeniu, lecz raczej w sensie fenomenologicznym, nie zawiera bowiem żadnych zaleceń dotyczących szczęśliwego czy choćby godziwego życia. Wyjaśnia natomiast pośrednio, dlaczego po refutacji marksizmu kontrkultura zainteresowała się na przykład psychoanalizą, a nawet próbowała, jak choćby jeden z naczelnych kontrkulturowych ideologów Herbert Marcuse, łączyć seksualną tematykę teorii Freuda z pseudohumanizmem Marksa (por. Marcuse 1998). Marks bowiem w przeciwieństwie do Freuda pominął kwestię tego, czym ludzie będa się zajmować po rewolucji. Jednakże psychoanaliza nie mogła stać się substytutem utraconej marksistowskiej metanarracji, ponieważ jak trafnie zauważa Allan Bloom, samopoznanie nie oznaczało dla Freuda poznania swojego miejsca w porządku wszechrzeczy (Bloom 2012: 177). Wydaje się, że kontrkultura istotnie rozczarowała się potencjałem teorii Freuda, jeśli chodzi o sztukę samopoznania, i rozpoczęła poszukiwania gdzie indziej.

Możemy w tych poszukiwaniach dopatrywać się pewnej konsekwencji, jeśli spojrzymy na nie właśnie z perspektywy koncepcji świadomości mitycznej. I tak, antyracjonalizm i antyliberalizm cechujące kontrkulture mają źródła w przeszczepionej na grunt amerykański filozofii niemieckiej, wywodzącej się od Nietzschego, a kontynuowanej przez Heideggera. Freud i Weber moga tutaj uchodzić, choć wcale nie jest to oczywiste, za uczniów i kontynuatorów tej tradycji w prostej linii (por. Maślanka 2003: 81-93). Do implementacji myśli Nietzschego na gruncie amerykańskim przyczynił się Max Weber i to właśnie za jego sprawą możliwa była mitotwórcza i religijna interpretacja życia społecznego. Musimy wobec tego być świadomi, że zaciagamy dług wobec klasycznej niemieckiej socjologii, ilekroć analizujemy zmitologizowaną świadomość kontrkultury. Socjologia Webera, patrząc z dzisiejszej perspektywy niepowodzeń marksizmu, musiała być naturalną konsekwencją tej porażki. Próbowała bowiem wyjaśnić, że powstanie kapitalizmu nie było, jak sądził Marks, wynikiem nieubłaganej logiki procesów historycznych, lecz konsekwencja przyjęcia takich, a nie innych wartości oraz obrazów świata. Można również interpretować potrzebę odnoszenia się do pozaempirycznej realności bezwarunkowej jako rezultat trwogi wobec wykorzenienia. O ile u Marksa świat post mortem Dei jest rzeczywistością wyzwoloną, o tyle u samego Nietzschego trudno 
dopatrzeć się optymizmu i słynna sentencja „Bóg umarł” bynajmniej do niego nie skłania. Śmierć Boga oznacza w rzeczywistości coś zupełnie odwrotnego niż nagminnie przypisywany Nietzschemu ateizm, przywracając religii kluczową rolę w nowożytnej kulturze oraz filozofii. Obecność mitu kontynuuje zatem te wątki nietzscheańskie, które potępiają naukowy światopogląd jako zabójczy dla kultury. Zatem jeśli tezy o nietzscheańsko-heideggerowskim rodowodzie kontrkultury nie wzbudzaja już dzisiaj specjalnych kontrowersji, to takowych nie powinno budzić, jak mi się zdaje, również odwołanie się do koncepcji świadomości mitycznej.

Argumentacja, którą proponuję, nie powinna być odczytywana ani jako wyraz fascynacji dokonaniami pewnego pokolenia, ani też jako idealistyczna interpretacja duchowych poszukiwań kontrkultury. Przeciwnie, nasuwa mi się tutaj kilka wniosków krytycznych. Po pierwsze - zasadnicze pytanie, czy kontrkultura nie strywializowała myślenia mitycznego w rozumieniu Kołakowskiego. Trudno ustalić, czy takie terminy jak samorealizacja, poszerzanie świadomości i samopoznanie mają swoje źródło w próbie przezwyciężania fenomenu obojętności świata, o którym była mowa w tym artykule, czy też należą do szerokiego zasobu zwrotów służących do mówienia o niczym. Być może tezy z pracy Kołakowskiego, poruszając jakieś czułe struny w duszach przedstawicieli kontrkultury, zostały przyswojone jako element stylu życia oraz komponent skutecznej autostylizacji. Nawiasem mówiąc, taki był pierwotny sens określenia „styl życia” w Ameryce, stosowany do opisu sposobu życia ludzi, którzy robią coś interesującego, ale społecznie nieakceptowanego; styl życia był więc, podobnie jak w przypadku cyganerii w Europie, synonimem amerykańskiej kontrkultury. Można mieć wobec tego uzasadnione wątpliwości, czy filozofia mitu została należycie zrozumiana i czy pod hasłami nowej duchowości nie kryła się prosta chęć odróżnienia się od innych. Tego rodzaju wątpliwości nasuwają się zwłaszcza w przypadku amerykańskiej kontrkultury, gdzie jak określił to Allan Bloom, nawet nihilizm jest pewnym nastrojem, nihilizmem bez otchłani (2012: 198), a nie efektem procesu dziejowego. Bloom powatpiewa także i w to, by młodzi kontestatorzy interesowali się tym, co sprawiedliwe i szlachetne. Poza troską o własne ego niewiele ich interesuje i jak sarkastycznie stwierdza autor Umystu zamknietego, gdyby nie Freud, większość z nich nigdy nie usłyszałaby o Edypie. Z drugiej strony przeciwstawianie europejskiej „głębi” amerykańskim „mieliznom”, a także tezę o braku „podpiwniczenia” amerykańskiej duszy, traktować można jako co najwyżej powierzchowną charakterystykę różnic pomiędzy amerykańską a europejską kontrkulturą (Bloom 2012: 199-201). Zresztą wydaje się, że z analiz amerykańskiego konserwatysty wyciagnąć można znacznie 
poważniejszy dla prezentowanej tutaj problematyki wniosek, że kontrkultura stanowiła w istocie kolejną obok liberalizmu czy socjalizmu ideologię, próbująca zmierzyć się z nihilizmem, względnie przezwyciężyć go. Po drugie, co nie mniej istotne, Obecnośc mitu stanowi moim zdaniem wyjaśnienie porażki kontrkultury jako ideologii skupionej w pewnym momencie na kwestiach wyzwolenia seksualnego, z czym zresztą w potocznym rozumieniu bywa zwykle kojarzona. Przywoływane tu skrótowo analizy, w których Kołakowski pokazuje, jak akt seksualny nie znosi fenomenu obojętności świata, lecz przeciwnie, jedynie pogłębia obcość człowieka i świata, dobitnie uzmysławiają iluzje rewolucji seksualnej, która stała się częścią popkulturowej rzeczywistości natychmiastowej gratyfikacji.

Konflikt pomiędzy racjonalną świadomością a irracjonalnym światem stanowi strukturalny komponent społecznego Lebenswelt. Mówiąc prościej, nietzscheańskie poczucie tragizmu egzystencji, permanentnego konfliktu wartości, zostało wyparte przez kontrkulturowe dążenie do harmonii z otoczeniem, społeczeństwem i wreszcie z samym sobą. Jakkolwiek kontrkultura w sensie genetycznym była możliwa, co starałem się w tym artykule uzasadnić, jako rezultat rozpoznania owych potrzeb konstytutywnych dla świadomości mitycznej, to jednak osiagnęła poziom kultury masowej, jeśli chodzi o ich zaspokojenie. Antycypację śmierci własnej, o której pisze Kołakowski, zastapiły ćwiczenia „,bycia na luzie” ze śmiercia, wiecznościa, Bogiem czy miłością. Strukturalne napięcia pomiędzy światem a świadomością człowieka, które rodzą realne konflikty, będące dla Nietzschego warunkiem twórczości, stały się dla pokolenia kontrkultury sygnałem, że należy wyruszyć w podróż do Indii lub udać się do psychoterapeuty. Następstwem kontestacji stało się raczej to, co socjologowie kultury nazywaja zasadą wspólnego mianownika, czyli homogenizacja treści kulturowych, a zatem - mówiąc wprost - jej umasowienie, nie zaś pozostające w sferze pobożnych życzeń uduchowienie. Krytyka ta nie odnosi się wyłącznie do europejskich odłamów kontrkultury. Obraz amerykańskiej kontrkultury lat 60. jest, jak zauważa Bloom, równie silnie zmitologizowany, tworzący złudzenie, że to ruchy młodzieżowe, realizując politykę emancypacji, przyczyniły się do powszechnego wyzwolenia mniejszości etnicznych czy seksualnych. W rzeczywistości sytuacja była jednak dokładnie odwrotna: był to okres dogmatycznych haseł i trywialnych dokonań, a także powszechnie panującego przekonania o moralnym zaangażowaniu studentów (Bloom 2012: 421-425). Pozornie zakorzenione w strukturze mitycznej świadomości samorozwój, emancypacja czy samopoznanie były jedynie moralnym sztafażem, za którym stała silnie hedonistyczna kultura konsumpcji z całym wachlarzem środków służących manifestowaniu 
uprzywilejowanej pozycji społecznej. Ponadto obniżyły się standardy edukacji na najlepszych amerykańskich uniwersytetach, a zapoczątkowany w tamtych latach dyskurs autoekspresji, jednoznacznie pozytywnie waloryzując osobisty samorozwój, doprowadził do spadku zainteresowania sprawami publicznymi, schlebiając jedynie pospolitym gustom.

Nasuwa się tutaj jednak poważniejsze pytanie. Czy takie motywy działania, które chcieliby uznać za realne przedstawiciele kontrkultury, były istotnie decydujacym czynnikiem zmian historycznych w latach 60. i 70.? Wydaje się, że na pytanie to trzeba odpowiedzieć przecząco, a rola studentów w przeprowadzaniu zmian politycznych, które z czasem doprowadziły do wzrostu świadomości grup marginalizowanych, była znikoma.

Wnioski z powyższych rozważań nie skłaniają wobec tego do optymizmu. Obecność mitu odczytywać można wprawdzie jako manifest pokolenia kontrkultury, lecz jego postulaty nigdy nie zostały zrealizowane. W zadaniu poszukiwania sensu w obliczu niepewności marksizmu nie zastapiła żadna alternatywna kontrkulturowa ideologia. Głód zmitologizowanej świadomości nadal podsycały owe uniwersalne, wbudowane w całość bytu ludzkiego potrzeby, tyle tylko, że kontrkultura nie była w stanie tego głodu zaspokoić. Pragnienie życia w uporządkowanym świecie pozostało, lecz uboga kulturowo dieta nie zdołała odżywić produkującej mity świadomości - a ubóstwo nękane pragnieniami to, jak zauważył Sandor Marai, piekło na ziemi.

Bibliografia:

/// Alexander J. 1987. Twenty Lectures, Sociological Theory since World War II, Columbia University Press, New York.

/// Alexander J. 2010. Machina informatyczna jako sacrum i profanum, [w:] Znaczenia społeczne. Studia z. socjologii kulturowej, tłum. S. Burdziej, J. Gądecki, Zakład Wydawniczy Nomos, Kraków.

/// Alexander J., Sherwood S., Smith Ph. 1993. Risking Enchantment. Theory and Methodology in Cultural Analisis, „Culture” 1993, nr 8(1), s. 10-14.

/// Bloom A. 2012. Umyst zamkniety. O tym jak amerykańskie sqkolnictwo uysisze zawiodto demokracje $i$ zubosyto dusze dzisiejszych studentón, tłum. T. Bieroń, Wydawnictwo Zysk i S-ka, Poznań.

/// Burska L. 2012. Awangarda i inne żudzenia. O pokolenin '68 w Polsce, Wydawnictwo Słowo/Obraz Terytoria, Gdańsk. 
/// Eliade M. 2008. Sacrum a profanum. O istocie sfery religijnej, tłum. B. Baran, Wydawnictwo Aletheia, Warszawa.

/// Eliade M. 2009. Traktat o historii religii, tłum. J. W. Kowalski, Wydawnictwo Aletheia, Warszawa.

/// Fromm E. 2005. Mieć ca̧y być?, tłum. J. Karłowski, Dom Wydawniczy Rebis, Poznań.

/// Gombrowicz W. 1997. Džiennik, t. I-III, Wydawnictwo Literackie, Kraków.

/// Hobsbawm E. 1999. Wiek skerajności. Spojrzenie na Krótkie Dwudqieste Stulecie, tłum. J. Kalinowska-Król, M. Król, Politeja, Świat Książki, Warszawa.

/// Jawłowska A. 1975. Drogi kontrkultury, Państwowy Instytut Wydawniczy, Warszawa.

/// Kijowski A. 1985. W środku śycia, w potowie drogi, „Przegląd Katolicki” 1985, nr 29(57).

/// Kłoczowski J. A. 1994. Więcej niż mit. Les₹ka Kołakowskiego spory o religie, Społeczny Instytut Wydawniczy Znak, Kraków.

/// Kołakowski L. 1972. Obecność mitu, Instytut Literacki, Paryż.

/// Kołakowski L. 1988. Gtówne nurt marksižmu, t. I-III, Aneks, Londyn.

/// Kołakowski L. 1989. Kapłan i błazen, [w:] Pochwała niekonsekwencji. Pisma rozproszone z lat 1955-1968, t. II, wybór i oprac. Z. Mentzel, Puls, Londyn.

/// Kołakowski L. 2006a. Odwet sacrum w kulturze swieckiej, [w:] Cay diabet może być zbawiony i 27 innych kazań, Społeczny Instytut Wydawniczy Znak, Kraków.

/// Kołakowski L. 2006b. Diabet, [w:] Cay diabet może być z̧bawiony i 27 innych kazań, Społeczny Instytut Wydawniczy Znak, Kraków.

/// Kołakowski L. 2008. Czas ciekany, czas niespokojny. Z Leszkiem Kołakowskim rozmawia Zbigniew Mentzel, cz. II, Społeczny Instytut Wydawniczy Znak, Kraków.

/ / Kołakowski L. 2012. Jednostka i Nieskończoność. Wolnosí i antynomie wolności w filozofii Spinozy, Wydawnictwo Naukowe PWN, Warszawa.

/// Legutko R. 1999. O czasach chytrych i prawdach pozornych, Wydawnictwo Stalky \& Co, Kraków. 
/// Lukács G. 2013. Historia i śniadomość klasowa. Studia o marksistowskiej dialektyce, tłum. M. J. Siemek, Wydawnictwo Naukowe PWN, Warszawa.

/// Marcuse H. 1998. Eros i cymilizacja, tłum. H. Jankowska, A. Pawelski, Wydawnictwo Literackie MUZA, Warszawa.

/// Maślanka T. 2003. Narodziny biurokracji z ducha nibilizmu. Weber i Nietzsche, [w:] Wokót socjologii polityki Maxa Webera, red. P. Woroniecki, C. Olbromski, Wydawnictwo Wyższej Szkoły Informatyki i Ekonomii Towarzystwa Wiedzy Powszechnej, Olsztyn.

/// Miłosz Cz. 1999. Zniewolony umyst, Wydawnictwo Literackie, Znak, Kraków.

/// Rawls J. 2013. Teoria sprawiedliwości, tłum. M. Panufnik, J. Pasek, A. Romaniuk, PWN, Warszawa.

/// Ricoeur P. 1986. Symbolika zła, tłum. S. Cichowicz, M. Ochab, Wydawnictwo Pax, Warszawa.

/// Tönnies F. 2008. Wspólnota i stowarayszenie. Rozprawa o komunizmie i socjalizmie jako empirycznych formach kultury, tłum. M. Lukasiewicz, Wydawnictwo Naukowe PWN, Warszawa.

/// Walicki A. 1996. Marksižm i skok do królestwa wolności. Džieje komunistycznej utopii, Wydawnictwo Naukowe PWN, Warszawa.

\section{/// Abstrakt}

W artykule podejmuje próbę zastosowania stworzonego przez Leszka Kołakowskiego pojęcia świadomości mitycznej do analiz rzeczywistego stanu świadomości pokolenia ‘68. Kategoria świadomości zmitologizowanej wywiedziona pośrednio z rozprawy Obecność mitu posłuży do interpretacji kontrkulturowej rewolty jako odpowiedzi na rozpad sensotwórczych metanarracji, w tym przede wszystkim marksizmu. Rewizja, a później całkowita refutacja marksizmu, który dla pokolenia kontrkultury stanowił jeden z kluczowych punktów odniesienia, ujmowane są nie jako odrzucenie określonych przekonań politycznych, lecz jako załamanie się wiary w porządkującą moc tej ideologii oraz w jej zdolności do nadawania sensu działaniom ludzi. Uniwersalność mitu wynika u Kołakowskiego ze struktury świadomości mitycznej, a intencjonalna obecność korelatów tej świadomości stanowi odpowiedź na potrzeby wbudowane w rzeczywistość bytu ludzkiego. Kontrkultura jest tutaj ujmowana jako odpowiedź na fundamentalne potrzeby egzystencjalne, które wynikają ze sposobu 
organizacji ludzkiej świadomości, a nie jako reakcja na przełomowe wydarzenia polityczne. Analiza taka uwypukla kulturowy, a nie tylko polityczny charakter zmian społecznych, sugerując ponadto, że kontrkultura była fenomenem bardziej uniwersalnym, wykraczającym poza lokalne historyczne uwarunkowania.

Słowa kluczowe:

kontrkultura, Leszek Kołakowski, marksizm, mit, pokolenie ‘68

\section{/// Abstract}

In this paper I make an attempt to apply mythical concept of consciousness, created by Leszek Kołakowski, to the analysis of actual state of consciousness of the generation ' 68 . The category of mythologized consciousness derived indirectly from The Presence of Myth will serve to interpret the countercultural revolt as a response to the breakdown of meaningful metanarratives, including primarily Marxism. Attempts to revise and later a total refutation of Marxism, which has been the key reference point for the generation of counterculture are recognized not as a rejection of certain political beliefs, but as the collapse of faith in the organizing power of this ideology and its ability to give meaning to human activities. The universality of the myth stems from the structure of mythical consciousness and the presence of intentional correlates of this consciousness is a response to the fundamental human needs. Hence, counterculture is here presented as a response to the fundamental existential needs that arise from the organization of human consciousness, and not as a reaction to landmark in political history. This analysis puts the emphasis on the cultural dimension of social change rather than political, suggesting that the counterculture was more universal phenomenon, which goes beyond the local historical circumstances.

Keywords:

counterculture, Leszek Kołakowski, Marxism, myth, generation '68 